\title{
COMPARISON OF PREDICTED BINDERS IN Rhipicephalus (Boophilus) microplus INTESTINE PROTEIN VARIANTS BM86 CAMPO GRANDE STRAIN, BM86 AND BM95*
}

\author{
RENATO ANDREOTTI ${ }^{1}$, MARISELA S. PEDROSO ${ }^{2}$, ALEXANDRE R. CAETANO ${ }^{3}$, NATÁLIA F. MARTINS ${ }^{3}$
}

\begin{abstract}
ANDREOTTI, R.; PEDROSO, M.S.; CAETANO, A.R.; MARTINS, N.F. Comparison of predicted binders in Rhipicephalus (Boophilus) microplus intestine protein variants Bm86 Campo Grande strain, Bm86 and Bm95. [Comparação da previsão de ligação das variantes de proteína de intestino de Rhipicephalus (Boophilus) microplus Bm86 cepa Campo Grande, Bm86 e Bm95]. Revista Brasileira de Parasitologia Veterinária, v. 17, n. 2, p. 93-98, 2008. Department of Animal Health, Embrapa Beef Cattle, C.P. 154, Campo Grande, MS 79002-970, Brazil. E-mail andreott@cnpgc.embrapa.br

This paper reports the sequence analysis of Bm86 Campo Grande strain comparing it with Bm86 and Bm95 antigens from the preparations TickGard ${ }^{\mathrm{PLUS}}$ and $\mathrm{Gavac}^{\mathrm{TM}}$, respectively. The PCR product was cloned into pMOSBlue and sequenced. The secondary structure prediction tool PSIPRED was used to calculate alpha helices and beta strand contents of the predicted polypeptide. The hydrophobicity profile was calculated using the algorithms from the Hopp and Woods method, in addition to identification of potential MHC class-I binding regions in the antigens. Pair-wise alignment revealed that the similarity between Bm86 Campo Grande strain and Bm86 is $0.2 \%$ higher than that between Bm86 Campo Grande strain and Bm95 antigens. The identities were 96.5\% and 96.3\% respectively. Major suggestive differences in hydrophobicity were predicted among the sequences in two specific regions.
\end{abstract}

KEY WORDS: Rhipicephalus (Boophilus) microplus, tick, Bm86, Bm95, antigen.

\section{RESUMO}

O objetivo deste estudo foi analisar a seqüência de Bm86 cepa Campo Grande comparando-a com os antígenos Bm86 e Bm95 das preparações TickGard ${ }^{\text {PLUS }}$ e Gavac ${ }^{\mathrm{TM}}$, respectivamente. O produto de PCR foi clonado em PMOSBlue e seqüenciado. Para calcular os conteúdos de alfa-hélice e fita beta do polipeptídio previsto, foi utilizada a ferramenta de prognóstico de estrutura secundária PSIPRED. O perfil de hidrofobicidade foi calculado usando os algoritmos de Hopp e Woods, além da identificação das possíveis regiões de ligação com MHC classe I nos antígenos. O alinhamento "pair-wise" revelou que a similaridade entre Bm86 cepa Campo Grande e Bm86 é 0,2\% maior que aquela entre Bm86 cepa Campo Grande e Bm95. As identidades foram de

\footnotetext{
* Supported by Fundect/MS and CNPq.

${ }^{1}$ Departamento de Saúde Animal, Embrapa Gado de Corte, C.P. 154, Campo Grande, MS 79002-970, Brazil. andreott@cnpgc.embrapa.br

${ }^{2}$ Departamento de Biotecnología Animal, Centro de Ingeniería Genética y Biotecnología, Ave 31E, 158 y 190, Rpto, P.O. Box 6162, CP 10600, Havana, Cuba.

${ }^{3}$ Embrapa Recursos Genéticos e Biotecnologia, Final W5 Norte, C.P. 02372; Brasília, DF 70770-900, Brazil
}

96,5\% e 96,3\%, respectivamente. Com relação à hidrofobicidade, os resultados sugerem que a maior diferença entre as seqüências está localizada em duas regiões específicas.

PALAVRAS-CHAVE: Rhipicephalus (Boophilus) microplus, carrapato, Bm86, Bm95, antígeno.

\section{INTRODUCTION}

Tick control remains a serious problem for cattle farms in Brazil. Limited success is achieved when acaricides are used as the main control method, and major drawbacks are associated with development of resistance by ticks and chemical residue toxicity in the environment and animal products (GRISI et al., 2002). The use of vaccines for tick control in association with chemicals and pasture rotation may open possibilities for integrated control, reducing the problems caused by development of resistance by the parasites and environmental and food product contamination (GARCIAGARCIA et al., 2000).

An effective vaccine was developed based on the Rhipicephalus (Boophilus) microplus gut Bm86 antigen (KEMP et al., 1989; DE LA FUENTE et al., 1995). The 
recombinant Bm86-containing vaccines Gavac ${ }^{\mathrm{TM}}$ (BOUÉ et al., 1999; Heber Biotec S.A., P.O. Box 6162, Havana, Cuba) and TickGard $^{\text {PLUS }}$ (WILLADSEN, 1997; Intervet Australia Pty. Ltd., 91-105 Harpin Street Bendigo, East Vic.) have been shown to be effective in providing immune protection against this cattle tick (DE LA FUENTE et al., 1998; DE LA FUENTE et al., 1999; WILLADSEN; KEMP, 1988), especially when combined with acaricides (REDONDO et al., 1999).

However, regional $R$. (B.) microplus strains, such as the Argentinian R. (B.) microplus strain A, have shown varied sensitivity to antibodies produced by Gavac $^{\mathrm{TM}}$ and TickGard ${ }^{\text {PLus }}$. Further research is therefore necessary to identify and develop additional antigens that might prove effective against a broader spectrum of tick strains (GARCIAGARCIA et al., 1999).

The Bm95 antigen was effective in protecting cattle against infestations with different tick strains, including the $R$.(B.) microplus strain A, in a pen trial under production conditions, decreasing ticks numbers on vaccinated animals and, therefore, reducing the frequency of acaricide treatments needed (GARCIA-GARCIA et al., 2000).

The Bm86 protein (RAND et al., 1989) and its variant Bm95 (GARCIA-GARCIA et al., 1999) are the only two vaccine antigens produced commercially. The observed variable efficacy of these antigens on cattle tick strains found in different geographic areas might be due to naturally occurring allelic variations present in the bm86 gene (DE LA FUENTE; KOCAN 2003).

In this paper we report the results of sequencing $b m 86$ cDNA (Campo Grande strain - bm86-CG) and conducting bioinformatics analysis, comparing previously reported $b m 86$ and bm95 sequences, to predict structural and immunogenicity differences in the proteins they codify, aiming at evaluating the reported differences in their antigenic performance.

\section{MATERIAL AND METHODS}

Ticks. $R$. (B.) microplus engorged female ticks collected in Campo Grande (20²7'S, 54 $37^{\circ} \mathrm{W}$ ), Mato Grosso do Sul, central Brazil, were placed in B.O.D. incubators for oviposition under $28{ }^{\circ} \mathrm{C}$ and $80 \%$ humidity. Eggs were kept under the same conditions until hatching.

RNA extraction, cDNA synthesis and amplification of the target sequence. The RNA from about $100 \mathrm{mg}$ of larvae was extracted using TRIZOL ${ }^{\mathrm{TM}}$ (Invitrogen USA), according to manufacturer's instructions. cDNA was synthesized from total RNA using the TermoScript ${ }^{\mathrm{TM}}$ RT PCR System for RTPCR kit (Invitrogen USA) and used as template in PCR reactions with primers (forward: 5'-ATCATCCATT TGCTCTGACTT-3'; reverse: 5'-AGCACTTGACTTTC CAGGATC-3') based on the previously published bm86 sequence (GenBank acc. \# M29321).

PCR reactions were performed as follows: 1x PCR buffer, $1.5 \mathrm{mM} \mathrm{MgCl}, 0.2 \mathrm{mM}$ dNTPs (Invitrogen USA), $2 \mathrm{~mL}$ cDNA, 1.6 U Platinum ${ }^{\mathrm{TM}}$ taq DNA polymerase (Invitrogen
USA) and $0.8 \mathrm{pM}$ of the primers in a final volume of $25 \mathrm{~mL}$. Reactions were carried out at $95^{\circ} \mathrm{C}$ for $5 \mathrm{~min}$, followed by 35 cycles of $95^{\circ} \mathrm{C}$ for $45 \mathrm{~s}, 55^{\circ} \mathrm{C}$ for $45 \mathrm{~s}, 72^{\circ} \mathrm{C}$ for $2 \mathrm{~min}$ and a final step of $72{ }^{\circ} \mathrm{C}$ for $10 \mathrm{~min}$.

Cloning and sequencing. PCR products were purified after electrophoresis in $0.8 \%$ agarose gels and cloned into pMOSBlue (Amersham Biosciences UK), according to manufacturer's instructions. Colonies were characterized by PCR with primers on the vector. Positive clones were sequenced with an ABI 3100 automated sequencer using BigDye terminator chemistry, according to manufacturer's instructions (Bm86-CG, Acc \# EU352677).

Sequence analysis. Comparisons of the predicted amino acid sequences from Bm86-CG, Bm86 (Acc. AF150895) and Bm95 (Acc. AF150891) were made using ClustalW from the BIOEDIT suite (HALL, 1999).

Hydrophobicity profile. Hydrophobicity profiles were calculated using the algorithms from Hopp and Woods (1981) and Kyte and Doolittle (1982) with the aforementioned sequences to identify predicted regions of hydrophilicity that are likely to be potential sites of antigenicity.

MHC binding prediction. The ProPred-I on-line service (http://www.imtech.res.in/) was used to identity potential MHC class-I binding regions in the three aforementioned predicted amino acid sequences. Peptides having a score greater than a selected threshold of $4 \%$ were considered as predicted binders for selected MHC alleles. Predicted binders are presented on each antigen sequence by a different color or along the primary sequence (SING; RAGHAVA, 2001).

\section{RESULTS AND DISCUSSION}

The bm86 gene from different $R$. (B.) microplus strains derived from various regions of Brazil and from some areas in Argentina, Colombia, Venezuela and Uruguay showed amino acid sequence variations ranging from $3.4 \%$ to $6.08 \%$ when compared to the recombinant Bm86 protein (acc. \# AAA30098, SOSSAI et al., 2005).

Garcia-Garcia et al. (1999) reported that amino acid sequence differences greater than $3.4 \%$ between the recombinant antigen and the endogenous Bm86 protein are sufficient to confer vaccination inefficiencies against different tick strains. Pair-wise alignment revealed that the similarity between Bm86-CG strain and Bm86 is 0.2\% higher than that between Bm86-CG strain and Bm95 antigens. The identities were $96.5 \%$ and $96.3 \%$ respectively.

The multiple sequence alignment shown in Figure 1 points out the amino acid identities and discrepancies across the three protein variants (Table 1). For Bm95 and Bm86-CG there are three and four substitutions, respectively; on the other hand, Bm86 has 18 substitutions. Further analyses of the amino acid sequence substitutions observed in Bm86-CG are associated with differences in hydrophobicity predictions (Figure 2).

The predicted surface exposure profiles of the three protein variants show the behavior expected for a globular protein. 


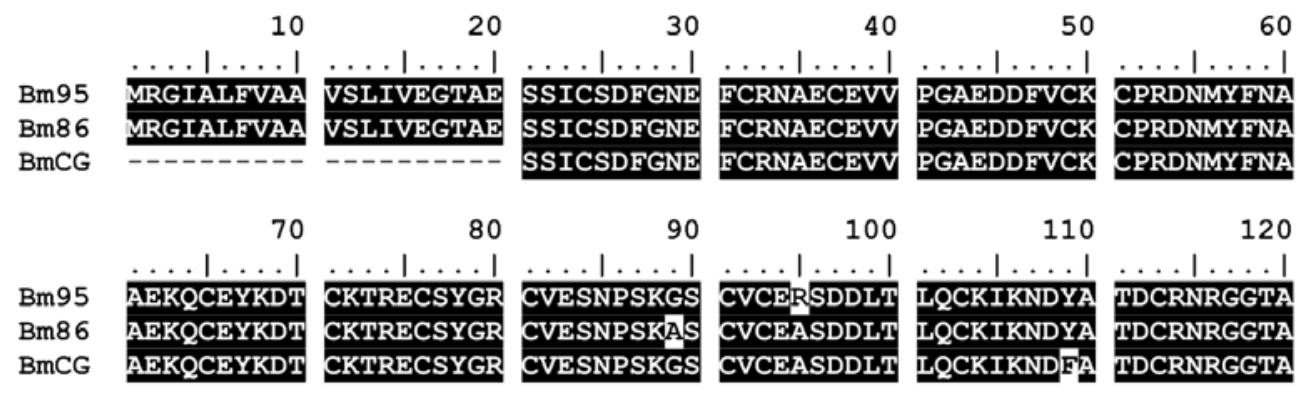

Bm95

Bm86

BmCG

140

150

160

170

180

$\ldots \ldots|\ldots|$
KLRTDGFIGA TCDCGEWGAM
KLRTDGTIGA
TCDCGEWGAM

KLRTDGFIGA

TCDCGEWGAY

NKTTRNCVPT

TCLRPDLTCK

DXEKNLLQR

DSRCCQGWNT

Bm95

Bm86

BmCG

$\ldots|\ldots| \ldots|\ldots| \ldots|\ldots| \ldots|\ldots| \ldots|\ldots| \ldots|\ldots| \ldots|\ldots| \ldots|\ldots|$

ANCSAAPPAD SYCSPGSPKG PDGQCKNACR TKEAGEVCKH GCRSTDKAYE CTCPSGSTVA

ANCSAAPPAD SYCSPGSPKG PDGQCINACK TKEAGEVCKH GCRSTGKAYE CTCPSGSTVA

ANCSAAPPAD SYCSPGSPKG PDGQCKNACR TKEAGFVCKH GCRSTDKAYE CTCPSGSTVA

Bm95

Bm86

BmCG

250

260

270

280

290

300

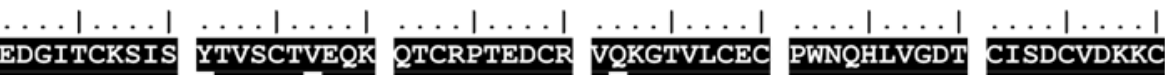
EDGITCKSIS HTVSCTAEQK QTCRPTEDCR VHKGTVLCEC PWNQHLVGDT CISDCVDKKC EDGITCKSIS YTVSCTVEQK QTCRPTEDCR VQKGTVLCEC PWNQHLVGDT CISDCVDKKC

Bm95

Bm86

BmCG

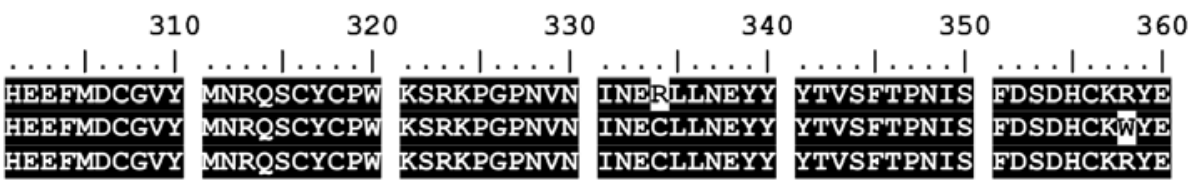

$\begin{array}{llllll}370 & 380 & 390 & 400 & 410 & 420\end{array}$

Bm95

Bm86

BmCG

DRVLGAIRTS IGKEVFKVEI INCTQDIKAR LIAEKPLSKY $\frac{\ldots}{\text { VLRKLQACEH }} \ldots$ PIGEWCMMYP DRVLEAIRTS IGKEVFKVEI LNCTQDIKAR LIAEKPLSKH VLRKLQACEH PIGEWCMMYP DRVLEAIRTS IGKEVFKVEI LNCTQDIKAR LIAEKPLSKY VLRKLQACEH PIGEWCMMYP

Bm95

Bm86

BmCG

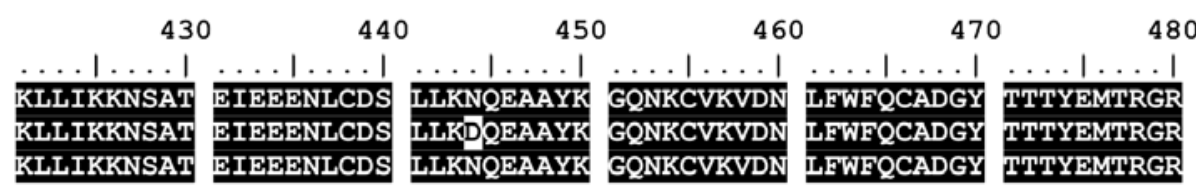

Bm95

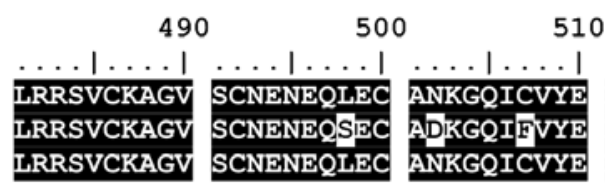
520
NGKANCQCPP
NGKANCQCPP
NGKANCQCPP 530

540

Bm86

BmCG

560

570

580

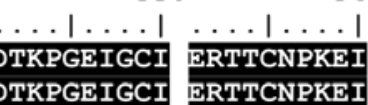

DTKPGEIGCI ERTTCNPKEI

Bm95

Bm86

BmCG $\ldots|\ldots| \ldots|\ldots| \ldots|\ldots| \ldots|\ldots| \ldots|\ldots| \ldots|\ldots| \ldots|\ldots| \ldots|\ldots|$ QECQDKKLEC QECQDKKLEC QECQDKKLEC

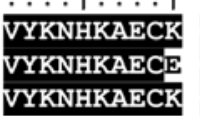

CPDDHECSR

CPDDHECYRE PAKDSCSEED NGKCQSSGQR CVIFNGKAVC CPDDHECSRE PAKDSCSEED NGKCQSSGQ

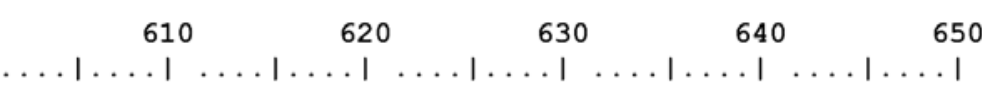

Bm95

Bm86

BmCG
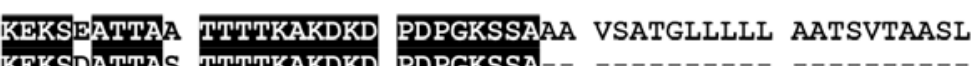

Figure 1. Multiple sequence analysis of Bm86, Bm95 and Bm86 Campo Grande strain performed with ClustalW. Legend: Bm86 (Acc. \# AF150895), Bm95 (Acc. \# AF 150891), Bm86-CG (Acc. \# EU352677) 
Table 1. Amino acid divergence between Boophilus microplus glycoproteins Bm86, Bm95 and Bm86 Campo Grande strain (Bm86-CG).

\begin{tabular}{ccccccccccccccccccc}
\hline Sequence & \multicolumn{11}{c}{ Amino acid/position } \\
\hline Bm95 & R95 & R334 & G365 & & & & \\
Bm86 & A89 & M142 & I206 & G226 & H251 & A257 & H272 & W358 & H400 & D444 & S498 & F557 & E560 & Y568 & I592 & K597 \\
& E605 & A610 & & & & & & & & & & & & \\
Bm86-CG & F109 & X162 & M592 & N597 & & & & & & & & & & \\
\hline
\end{tabular}

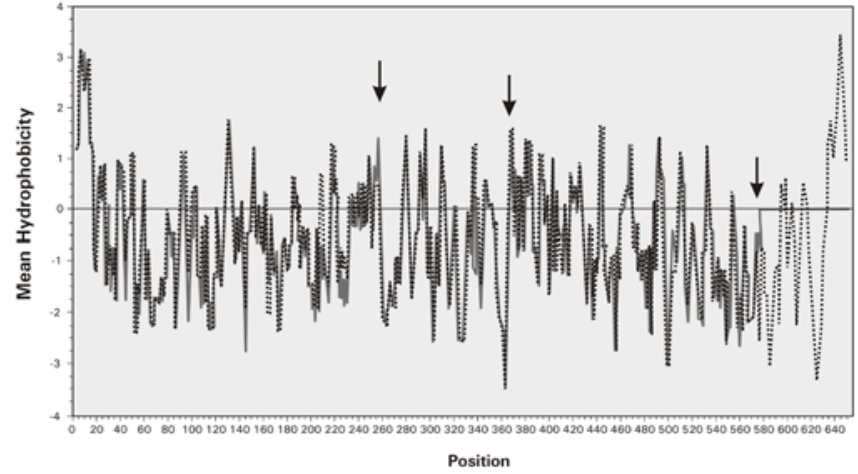

Figure 2. Kyte and Doolittle algorithm calculation for antigen proteins. Dotted gray, CG strain; gray, Bm95; dotted black, Bm86. Legend: Arrows show differences in hydrophobicity predictions.

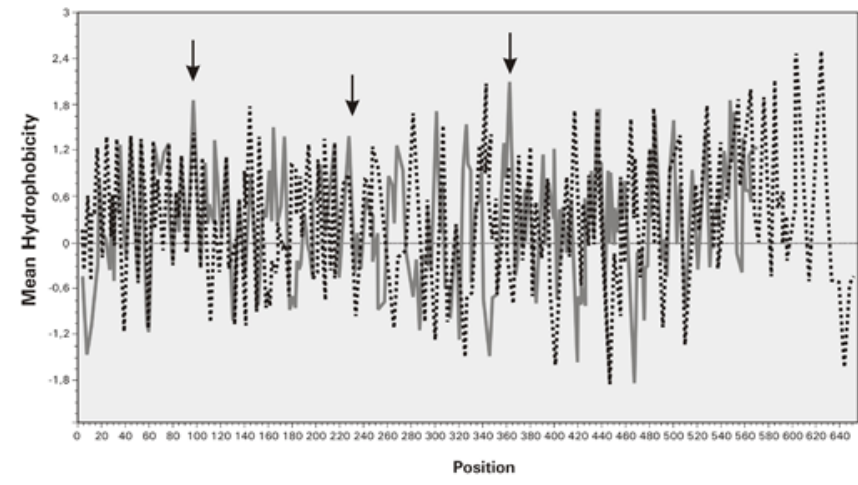

Figure 3. Hopp and Woods algorithm calculation for antigen proteins. Dotted gray, CG strain; gray, Bm95; dotted black, Bm86. Legend: Arrows show differences in hydrophobicity predictions.

No major differences were seen across the three protein variants. On the other hand, the hydrophilicity profile estimated for the three protein variants with the Hopp and Woods (1981) method suggests major differences (Figure 3).

The Bm95 variant shows three regions of high immunogenic potential that were not observed in the other variants. The first region, from R95 to T100 (RSDDLTL), is probably due to the hydophylicity of an Arginine residue. The second region, in position 226, corresponds to an Aspartic acid residue and the third region is at residue number 358 , corresponding to an Arginine. For the variant Bm86-CG strain, there were no higher hydrophilic peaks compared with Bm95, but two regions might be of higher immunogenicity: K141, in the sequence DLTCK, and the sequence DRVLEAIR at position 346. This suggests that the respective amino acid changes present in the Bm86-CG variant fall within protein regions normally available to antibody recognition in Bm86 and therefore have a high potential to interfere in the dynamics of antigen recognition. These findings corroborate the observed reduced efficacy of $\mathrm{Gavac}^{\mathrm{TM}}$ in protecting cattle raised in the Campo Grande region against the local $R$. (B.) microplus strain (ANDREOTTI et al., 2006).

$\mathrm{T}$ cells recognize antigens as peptide fragments complexed with MHC molecules, and cattle express high polymorphic classical MHC class I genes (HLA-A, HLA-B and HLA-C; BIRCH et al., 2006). MHC binding site predictions were performed with Bm86, Bm86-CG and Bm95 (results not shown), and with some synthetic peptide sequences derived from Bm86 (PATARROYO et al., 2002, results not shown).

MHC classes I and II have a binding site consisting of a beta-strand flanked by two alpha helices arranged as a pocket. The main difference between the two classes is in the dimensions of the peptide-binding groove, as class I is able to bind to 8-11 amino acid peptides and class II MHC has the capability to bind much larger peptides. The Bm86 protein variants analyzed showed a similar behavior for MHC binding prediction. All proteins and peptides analyzed showed that side chains form favorable hydrophobic environment needed to interact with MHC side chains. The observed differences were not significant with changes in the threshold (results not shown).

On the other hand Garcia-Garcia et al. (1999) suggested that variations greater than $2.8 \%$ in the protein amino acid sequence would be enough to confer vaccination inefficiencies when recombinant antigens were used. The results obtained by Sossai et al. (2005) upon analyzing variability of the bm86 gene in different $R$. (B.) microplus strains from various regions in Brazil and from some areas in Argentina, Colombia, Venezuela and Uruguay revealed variations from $3.4 \%$ to $6.08 \%$ in the homologous amino acid sequence of the $b m 86$ gene and, when compared with the $b m 95$ gene, variations from $1.14 \%$ to $4.56 \%$.

In conclusion, all peptides were predicted to probably bind to MHC class I. Further investigation with CD4+ T-cell immunogenic proteins and their epitopes would be necessary to make possible the development of MHC class II to both quantify antigen-specific lymphocytes and discover novel antigenic epitopes properties (BROWN et al., 2006).

The results suggest that the discrepancies in vaccination are not only related to sequence structural features, but might be due to host factor polymorphism. Therefore there is still a need for further studies on Bm86 Campo Grande strain antigen response. 


\section{REFERENCES}

ANDREOTTI, R.; GOMES, A.; MALAVAZI-PIZA, K.C.; SASAKI, S.D.; SAMPAIO, C.A.M.; TANAKA, A.S. BmTI antigens induce a bovine protective immune response against Boophilus microplus tick. International Immunopharmacology, v. 2, n. 4, p. 57- 563, 2002.

ANDREOTTI, R. Performance of two Bm86 antigen vaccine formulation against tick using crossbreed bovines in stall test. Revista Brasileira de Parasitologia Veterinária, v.15, n.3, p. 97-100, 2006.

BIRCH, J.; MURPHY, L.; MACHUGH, N.D.; ELLIS, S.A.. Generation and maintenance of diversity in the cattle MHC class I region. Immunogenetics, v.58, n. 8, p.670-679, 2006.

BOUÉ, O.; REDONDO, M.; MONTEIRO, C.; RODRIGUEZ, M.; DE LA FUENTE, J. Reproductive and safety assessment of the vaccination with $\mathrm{Gavac}^{\mathrm{TM}}$ against the cattle tick (Boophilus microplus). Theriogenology, v. 51, n. 8, p. 1547-1554, 1999.

BROWN, W.C.; NORIMINE, J.; KNOWLES, D.P.; GOFF, W.L.. Immune control of Babesia bovis infection. Veterinary Parasitology, v. 31, n.1-2, p. 75-87, 2006.

DA SILVA VAZ Jr, I.; LOGULLO, C.; SORGINE, M.; VELLOSO, F.F.; ROSA DE LIMA, M.F.; GONZALES, J.C.; MASUDA, H.; OLIVEIRA, P.L.; MASUDA, A.. Immunization of bovines with aspartic proteinase precursors isolated from Boophilus microplus eggs. Veterinary Immunology and Immunopharmacology, v. 66, n. 3-4, p. 331- 41, 1998.

DE LA FUENTE, J.; RODRÍGUEZ, M.; FRAGOSOS, H.; ORTIZ, M.; GARCIA, O.; GARCIA-GARCIA, J.C.; LLEONART, R. Efficacy of vaccination with Gavac ${ }^{\mathrm{TM}}$ in the control of Boophilus microplus infestations. Elfos Scintiae, v. 1, n. 1, p. 14-22, 1995.

DE LA FUENTE, J.; RODRIGUEZ, M.; REDONDO, M.; MONTER, C.; GARCIA-GARCIA, J.C.; MENDEZ, L.; SERRANOT, E.; VALDEST, M.V.; ENRIQUEZ, A.; CANALES, M.; RAMOS, E.; BOUÉ, O.; MACHADO, H.; LLEONART, R.; ARMAS, C.A.; REY, S.; RODRIGUEZ, J.L.; ARTILES, M.; GARCIA, L. Field studies and cost effectiveness analysis of vaccination with Gavac $^{\mathrm{TM}}$ against the cattle tick Boophilus microplus. Vaccine, v. 16, n. 4, p.366-849, 1998.

DE LA FUENTE, J.; RODRIGUEZ, M.; MONTEIRO, C.; REDONDO, M.; GARCIA-GARCIA, J.C.; MENDEZ, L.; SERRANO, E.; VALDEZ, M.; ENRIQUEZ, A.; CANALES, M.; RAMOS, E.; BOUÉ, O.; MACHADO, H.; LLEONARD, R. Vaccination against ticks (Boophilus spp.): the experience with the Bm86-based vaccine Gavac $^{\mathrm{TM}}$. Genetic Analysis: Biomolecular Engineering, v. 15, n. 3-5, p. 143-148, 1999.

DE LA FUENTE, J.; KOCAN K, M. Advances in the identification and characterization of protective antigens for recombinant vaccines against tick infestations. Expert Review of Vaccines, v. 2, n. 4, p. 583-593, 2003.
GARCIA-GARCIA, J.C.; GONZALES, I.L.; GONZALES, D.M.; VALDES, M.; MENDEZ, L.; LAMBERTI, J.; D’AGOSTINHO, B.; CITRONI, D.; FRAGOSO, H.; ORTIZ, M.; RODRIGUEZ, M.; DE LA FUENTE, J. Sequence variations in the Boophilus microplus Bm86 locus and implications for immunoprotection in cattle vaccinated with this antigen. Experimental and Applied Acarology, v. 23, n. 11, p. 883-895, 1999.

GARCIA-GARCIA, J.C.; MONTEIRO, C.; REDONDO, M.; VARGAS, M.; CANALES, M.; BOUÉ, O.; RODRIGUEZ, M.; JOGLAR, M.; MACHADO, H.; GONZÁLEZ, I.L.; VALDES, M.; MENDEZ, L.; DE LA FUENTE, J. Control of ticks resistant to immunization with Bm86 in cattle vaccinated with the recombinant antigen Bm95 isolated from the cattle tick, Boophilus microplus. Vaccine, v. 18, n. 21, p. 2275 -2287, 2000.

GRISI, L.; MASSARD, C.L.; MOYA BORJA, G.E.; PEREIRA, J.B. Impactos econômicos das principais ectoparasitoses em bovinos no Brasil. Hora Veterinária, v. 125, n. 1, p. 8-10, 2002.

HALL T.A. BioEdit: a user-friendly biological sequence alignment editor and analysis program for Windows 95/98/ NT. Nucleic Acids Symposium Series, n. 41, p. 95-98, 1999.

HOPP, T.P.; WOODS, K.R. Prediction of protein antigenic determinants from amino acid sequences. Proceedings of the National Academic Science, v. 78, p. 3824-3828, 1981.

JONES, D.T. Protein secondary structure prediction based on position-specific scoring matrices. Journal of Molecular Biology, v. 292, n. 2, p. 195-202, 1999.

KEMP, D.H.; PEARSAN, R.D.; GOUGH, J.M.; WILLADSEN, P. Vaccination against Boophilus microplus: localization of antigens on tick gut cells and their interaction with the host immune system. Experimental and Applied Acarolology, v. 7, n. 1, p. 43-58, 1989.

KYTE, J.; DOOLITTLE, R.F. A simple method for displaying the hydropathic character of a protein. Journal of Molecular Biology, v. 157, n. 1, p. 105-132, 1982.

MCGUFFIN, L.J.; BRYSON, K.; JONES, D.T. The PSIPRED protein structure prediction server. Bioinformatics, v. 16, n. 4, p. 404-405, 2000.

PATARROYO, J.H.; PORTELA, R.W.; DE CASTRO, R.O.; COUTO PIMENTEL, J.; GUZMAN, F.; PATARROYO, M.E.; VARGAS, M.I.; PRATES, A.A.; DIAS MENDES, M.A. Immunization of cattle with synthetic peptides derived from the Boophilus microplus gut protein (Bm86). Veterinary Immunology and Immunopharmacology, v. 88, n. 3-4, p. 163-172, 2002.

RAND, K.N.; MOORE, T.; SRISKANTHA, A.; SPRING, K.; TELLAN, R.; WILLADSEN, P.; COBON, S. Cloning and Expression of a protective antigen from the cattle tick Boophilus microplus. Proceedings of the National Academic Science, v. 86, p. 9657-9661, 1989.

REDONDO, M.; FRAGOSO, H.; ORTIZ, M.; MONTEIRO, C.; LONA, J.; MEDELLIN, J.A.; FRIA, 
R.; HERNANDEZ, V.; FRANCO, R.; MACHADO, H.; RODRIGUEZ, M.; DE LA FUENTE, J. Integrated control of acaricide resistant Boophilus microplus populations on grazing cattle in Mexico using vaccination with Gavac ${ }^{\mathrm{TM}}$ and amidine treatment. Experimental and Applied Acarolology, v. 23, n. 10, p. 841-849, 1999.

SINGH, H.; RAGHAVA, G.P. ProPred: prediction of HLADR binding sites. Bioinformatics, v. 17, n. 12, p. 12361237, 2001.

SOSSAI, S.; PECONICK, A.P.; SALES-JUNIOR, P.A.; MARCELINO, F.C.; VARGAS, M.I.; NEVES, E.S.; PATARROYO, J.H. Polymorphism of the Bm86 gene in South American strains of the cattle tick Boophilus microplus. Experimental and Applied Acarolology, v. 37, n. 3-4, p. 199-214, 2005.

TRIGUERO, A.; BLANCO, R.; MACHADO, H.; RODRIGUEZ, M.; DE LA FUENTE, J. Development of enzyme linked immunosorbent assay to measure Bm86 antigen of Boophilus microplus (cattle tick) and to detect anti-Bm86 antibodies in serum samples. Biotechnology Techniques, v. 13, n. 1, p. 119-125, 1999.

WILLADSEN, P.; KEMP, D.H. Vaccination with concealed antigens for tick control. Parasitology Today, v. 4, n. 7, p. 196-198, 1988.

WILLADSEN, P. Novel vaccines for ectoparasites. Veterinary Parasitology, v. 71, n. 2-3, p. 209-222, 1997.

Received on July 12, 2007.

Accepted for publication on April 01, 2008. 